\title{
Pharmacognosy
}

\section{Qualitative terpene profiling of Cannabis varieties cultivated for medical purposes}

\author{
Perfil de terpenos de variedades de Cannabis cultivadas para uso medicinal
}

\author{
Ernesto Diaz Rocha ${ }^{1}$, Vitória EA Silva ${ }^{1}$, Fernanda CS Pereira ${ }^{1}$, Valery M Jean ${ }^{1}$, Fabio L Costa Souza ${ }^{1}$, \\ Leopoldo Clemente Baratto ${ }^{2}$, Ana CM Vieira², Virgínia Martins Carvalho ${ }^{1,3,4}$
}

\begin{abstract}
With the upcoming medical Cannabis regulation, quality control methods on raw material will be required. Besides testing for contaminants and potency, there are also pharmaceutical and forensic interests in the determination of the terpene profile in different strains of Cannabis as complementary identification methods. A simple non-destructive HS-SPME GC-MS method was used to identify the terpene content in twelve Cannabis samples, four of them were of the hemp type (Harle-tsu), seven from various marihuana types and one of the intermediate type. They all were previously analyzed by HPLC to determine the potency (THC and CBD content). Spectral library matching was used to identify the terpenes compounds. Thirty terpenes compounds were detected, nine of them were present in all Cannabis samples and used to find their terpene profile: $\alpha$-pinene, $\beta$-pinene, $\beta$-myrcene, $D$-limonene, terpinolene, linalool, caryophyllene, $\alpha$-bergamotene and humulene. Three of them, caryophyllene, $\alpha$-pinene and $\beta$-myrcene were found as larger components in most of samples. A principal components analyses (PCA) was performed. The four hemp type samples showed two different profiles, two samples showed caryophyllene as main component and the others two with $\beta$-myrcene as such. The marihuana type samples showed wider profiles with no clear patterns at all, which is not surprising because of the low number of samples. The simple methodology shows viable to set the terpenes profile for analyses of raw Cannabis material. Suitability for differentiation between different sorts of types needs more studies, with increasing numbers of samples.
\end{abstract}

Key-words: Cannabis, chemical profile, GC-MS, HS-SPME, terpenes.

\section{Resumo}

A partir da iminente regulação da Cannabis para uso médico, métodos para o controle de qualidade desta matéria-prima serão necessários. Além de testes para contaminantes e potência, há também interesse farmacêutico e forense na determinação do perfil de terpenos nas diferentes variedades de Cannabis como método complementar de identificação. Um método HS-SPME GC-MS simples e não destrutivo foi usado para identificar o conteúdo de terpenoides em doze amostras de Cannabis, quatro delas do tipo cânhamo (Harle-tsu), sete diferentes do tipo maconha e uma do tipo intermédio. Todas foram previamente analisadas por HPLC para medir a potência através dos teores de THC e CBD. Comparação com a biblioteca de espectros foi usada para identificar os terpenos. Trinta compostos tipo terpeno foram detectados, nove deles estavam presentes em todas as amostras em níveis significativos, os quais foram usados para definir o perfil de terpenos: humuleno, cariofileno, D-limoneno, $\alpha$-pineno, $\beta$-pineno, $\beta$-mirceno, linalool, terpinoleno e $\alpha$-bergamoteno. Três deles, cariofileno, $\alpha$-pineno e $\beta$-mirceno resultaram em maior quantidade na maioria das amostras. De acordo com

\footnotetext{
${ }^{1}$ Universidade Federal do Rio de Janeiro - UFRJ, Faculty of Pharmacy, Dep. Clinical and Toxicological Analysis, Av. Carlos Chagas Filho 373, Ilha do Fundão, Rio de Janeiro, RJ, 21941-902, Brazil.

${ }^{2}$ Universidade Federal do Rio de Janeiro - UFRJ, Faculty of Pharmacy, Dep. Natural Products and Food, Av. Carlos Chagas Filho 373, Ilha do Fundão, Rio de Janeiro, RJ, 21941-902, Brazil.

${ }^{3}$ ORCID: <https://orcid.org/0000-0003-1155-9101>

${ }^{4}$ Correspondent author: vmcfarm@gmail.com
} 


\begin{abstract}
a análise de componentes principais (PCA), as quatro amostras da variedade Harle-Tsu (perfil de cânhamo com $\mathrm{THC} / \mathrm{CBD}<1)$ apresentaram dois perfis diferentes, em duas amostras o componente majoritário foi o cariofileno, enquanto nas outras duas amostras o $\beta$-mirceno foi o componente majoritário. As amostras de maconha $(\mathrm{THC} / \mathrm{CBD}>1)$ mostraram perfis mais amplos, sem padrões claros que pode ser justificado pelo reduzido tamanho amostral. O método mostrou-se simples e viável para determinação do perfil de terpenos em matéria-prima vegetal de espécies do gênero Cannabis. Por outro lado, a atribuição de perfis químicos às variedades específicas necessita de mais estudos com maior tamanho amostral.
\end{abstract}

Palavras-chave: Cannabis, perfil químico, GC-MS, HS-SPME, terpenos.

\section{Introduction}

The first report about Cannabis was addressed to the Chinese, who described its medicinal properties in the Chinese Pharmacopoeia PenTs'ao Ching 2000 years ago. Assyrians considered Cannabis as the main drug of their Pharmacopoeia since 3000 years ago (Honório et al. 2006). The $1^{\text {st }}$ Brazilian Pharmacopoeia (1929) describes the Cannabis sativa L. var. indica, with the generic name "maconha", "meconha", "diamba" and "cannabis", indicating the flowered summits as a raw material in preparing Cannabis officinalis extract or fluid extract of India hemp, hemp powder and the Indian hemp dye (Silva 1929).

The Cannabis genus is considered to be monospecific (Cannabis sativa L.), which is divided into several subspecies (/Cannabis sativa subsp. indica (Lamarck) Small \& Cronquist, Cannabis sativa var. kafiristanica (Vavilov) Small \& Cronquist, Cannabis sativa var. ruderalis (Janisch.) Liou) (UNODC 2009; IPNI 2020). However, the chemical and morphological distinctions by which Cannabis has been divided into these subspecies are often not readily discernible. It appears to be environmentally modifiable, and vary in a continuous pattern. For most purposes, it will suffice to apply the name Cannabis sativa to all cannabis plants encountered (UNODC 2009).

The main compounds of Cannabis are the cannabinoids (phenolic terpenes). The major cannabinoids are tetrahydrocannabinolic acid (THCA) and cannabidiolic acid (CBDA), and when both are converted to their neutral forms tetrahydrocannabinol (THC) and cannabidiol (CBD), respectively, it is observed the pharmacological effects. THC is psychoactive, with antiemetic and analgesic effects, while CBD is a depressor with antiseizure, anxiolytic and anti-inflammatory properties (Honório et al. 2006; Hill 2015).

Among non-cannabinoid compounds, more than 100 volatile substances were already found in Cannabis, contributing mainly to its unique aroma as well to the pharmacological effects (Pavlovic et al. 2018; Iseppi et al. 2019). According to Ross \& ElSohly (1996) volatile oil from fresh buds is composed primarily of monoterpenes (92\%) and sesquiterpenes $(7 \%)$, but small amounts of alcohols, aldehydes, ketones and esters can be found as well (Pavlovic et al. 2018).

Cannabis terpenoids such as limonene, myrcene, $\alpha$-pinene, linalool, $\beta$-caryophyllene, caryophyllene oxide, nerolidol and phytol among others share a common precursor with cannabinoids in biosynthetic pathways. Most of them are all flavor and fragrance components common to human diets that have been generally recognized as safe by the United States Food and Drug Administration (FDA) and other regulatory agencies (Russo 2011).

Cannabinoids and terpenoids are synthesized inside Cannabis glandular trichomes (Potter 2009). Monoterpenes usually predominate (limonene, myrcene, pinene), but these headspace volatiles do suffer diminished yields with drying and storage, resulting in a higher relative proportion of sesquiterpenoids (especially caryophyllene), as also often occurs in extracts (Ross \& ElSohly 1996). Terpenoid production increases with light exposure, but decreases with soil fertility (Langenheim 1994). This is supported by the glasshouse experience that shows higher yields in plants with relative nitrogen deficiency just prior to harvest (Potter 2004), favoring floral over foliar growth. Volatile oils composition is more genetically than environmentally determined (Bassolé et al. 2010), despite vegetative propagation of high-performance plants under controlled environmental conditions (light, heat and humidity) (Potter 2009). Terpenoid components in concentrations above $0.05 \%$ are considered of pharmacological interest (Adams \& Taylor 2010). Animal studies are certainly 
supportive, mice exposed to terpenoid odors inhaled from ambient air for $1 \mathrm{~h}$ demonstrated profound effects on activity levels, suggesting a direct pharmacological effect on the brain, even at extremely low serum concentrations (e.g. linalool with $73 \%$ reduction in motility at $4.22 \mathrm{ng} \cdot \mathrm{mL}^{-1}$, pinene $13.77 \%$ increase at trace concentration, terpineol $45 \%$ reduction at 4.7 $\mathrm{ng} \cdot \mathrm{mL}^{-1}$ (Buchbauer et al. 1993).

Selective cross-breeding of high-terpenoidand high-phytocannabinoid-specific varieties are a rational target that may lead to improve the pharmacological approach to such disorders as treatment-resistant depression, anxiety, drug dependency and dermatological disorders, as well as industrial applications as safer pesticides and antiseptics. An interesting future with terpenoid Cannabis compounds may be achievable through further research of the entourage effect (synergistic effect).

The Brazilian Sanitary Agency (ANVISA) has authorized Cannabis extracts importation for medical purposes since 2015. Although the cultivation standards for drug research and production purpose are being formulated, the available Cannabis varieties in Brazil are still unknown or their studies are scarce in current scientific literature. The major difficulty to the authors lies in obtaining a sufficient number of samples of recognized origin, especially by legal reasons.

At Federal University of Rio de Janeiro (UFRJ), Brazil, an extension project, named Farmacannabis, was created to monitor the medical treatments with Cannabis products and to offer pharmaceutical support for patients or their parents who grow Cannabis and prepare their extracts with court authorization (Carvalho 2017). In order to study the chemical profile of Cannabis plants cultivated by individuals assisted by Farmacannabis project, a method by headspace solid-phase micro extraction (HS-SPME) and gas chromatography-mass spectrometry (GC-MS) was developed and the major volatile terpene profiles were identified to determine the differences among these plants and contributing for chemotaxonomic discrimination of the varieties of the species.

\section{Material and Methods}

\section{Collection and sampling}

Dried Cannabis flowers samples were obtained from plants cultivated by patients and patients' parents attended by Farmacannabis project. The growers reported the names of the cultivated varieties and the growing conditions. The samples were labeled in the laboratory by the reported names and by a code composed of letters and numbers (for example: SP001 means sample 1).

Twelve samples reported as being of the varieties Cinderella, Caetano Veloso, Harle-Tsu, Amnesia Haze, 24K Gold, Og Kush, Tolomelli and Cannatonic Cannabis were cultivated indoor and outdoor by cloning. According with report by growers the plants were kept under constant illumination, when they grew about $1 \mathrm{~m}$ high they were kept in cycles of light and darkness, $12 \mathrm{~h}$ for each cycle, for flourish. The flowers were harvest when the glandular trichomes showed brown color. The time between the beginning of cultivation and harvest was between 4 and 6 months.

After the harvest, growers removed the leaves and dried the flowers between 7 and 15 days in well-ventilated area, protected from light and moisture. The Cannabis flowers were transported to laboratory by patients or their parents and storage at $-20{ }^{\circ} \mathrm{C}$ until analysis is performed.

The sampling took place in the pharmaceutical support when individuals assisted by Farmacannabis requested information on the profile of the major cannabinoids, THC and CBD. Five cannabinoids, THC, THCA, CBD, CBDA and $\mathrm{CBN}$ were extracted from vegetable sample (100 mg) by organic solvents and quantified according De Backer et al. (2009) in a High Performance Liquid Chromatography system Thermo composed by quaternary pump model 600, type Rheos 5600, Accela autosampler and PDA Accela detector $20 \mathrm{~Hz}$. Data were processed using the ChromQuest 5.0 software. The calibration curves were performed at concentrations between 1.00 and $30.00 \mathrm{mg} / \mathrm{mL}$ for all cannabinoids with certified reference standards THC, CBD, THCA, CBDA and CBN $1.0 \mathrm{mg} / \mathrm{mL}$ purchased from Cerilliant Corporation and diazepam (7-chloro1-methyl-5-phenyl-3H-1,4-benzodiazepin-2-one; 99.9\% purity) purchased from National Institute of Quality Control in Health, Fiocruz, Brazil was used as internal standard.

The total THC (the sum of THCA, THC and $\mathrm{CBN}$ ) and total $\mathrm{CBD}$ (the sum of $\mathrm{CBDA}$ and $\mathrm{CBD}$ ) were used to calculate the $\mathrm{THC} / \mathrm{CBD}$ ratios and classified the specimen as hemp or marijuana according with the guidelines used by National Drug Analysis Laboratories of United Nations Office on Drugs and Crimes (UNODC, 2009) and by American Herbal Pharmacopoeia (AHP 
2013). Marijuana shows THC/CBD ratio $>1$ and hemp shows THC/CBD ratio < 1 (UNODC 2009). A distinction between "hemp" and "marijuana" is useful for patients to select the varieties of interest in seizures control (rich-CBD varieties) or in nausea and vomiting control in cancer patients (rich-THC varieties). The $\mathrm{THC} / \mathrm{CBD}$ ratio around 1 is classified as "intermediate" (AHP 2013).

Terpenes extraction and analysis

Samples were homogenized by pulverization and $100 \mathrm{mg}$ were introduced into a flat bottom 60 $\mathrm{mL}$ glass bottle with a rubber cap. The HS-SPME was performed with a $100 \%$ polydimethylsiloxane (PDMS) fiber Supelco, $100 \mu \mathrm{m}$ coating thickness, recommended for volatile compounds. The bottle with the sample was heated in a ceramic hot plate with digital temperature control at 50 ${ }^{\circ} \mathrm{C}$ for $10 \mathrm{~min}$. After the heating the SPME fiber was introduced and exposed into the head space bottle during 60 seconds and then the fiber was retracted and removed. Desorption procedure was done by injection in the GC-MS and exposed for 30 seconds in order to rich the full desorption of the volatile fraction $\left(250{ }^{\circ} \mathrm{C}\right.$ temperature in the injection port) and in split mode (ratio 20:1).

Previously, blanks from the fiber and bottle were analyzed in order to identify any potential interference from used material sources. The GC-MS qualitative analyses were performed in a Shimadzu GCMS QP 2010 ultra system with $30 \mathrm{~m} \mathrm{x}$ $0.25 \mathrm{~mm} \times 0.25 \mu \mathrm{m} 5 \%$ phenylmethylpolysiloxane capillary column (HP-5MS, Agilent), the oven temperature was set at $60{ }^{\circ} \mathrm{C}(5 \mathrm{~min})$, increased from $20^{\circ} \mathrm{C} \mathrm{min}^{-1}$ to $170^{\circ} \mathrm{C}(3 \mathrm{~min})$, increased from $20^{\circ} \mathrm{C} \mathrm{min}{ }^{-1}$ to $260^{\circ} \mathrm{C}$ (2 min). Helium 5.0 analytical grade purity was used as carrier gas at a flow of $1.21 \mathrm{~mL} \mathrm{~min}^{-1}$. Temperature applied were $250{ }^{\circ} \mathrm{C}$ for injector, $250^{\circ} \mathrm{C}$ for interface and 230 ${ }^{\circ} \mathrm{C}$ for ion source. Data were acquired in the full scan mode (50-500 m/z mass range).

Terpenes identification was done using mass spectrum computerized databases (NIST11) and by the linear index of retention (LRI). The integration parameters were settled to the 30 compounds with highest Total Ion Current (TIC) abundance. Nine terpenes were present in all samples and were used to compare the profiles: $\alpha$-pinene, $\beta$-pinene, $\beta$-myrcene, D-limonene, terpinolene, linalool, caryophyllene, $\alpha$-bergamotene and humulene.

Prism 7.0 software was used to show the distribution of nine terpenes in samples and to make the descriptive statistics. The PAST program was used to perform the principal component analysis (PCA), the relative TIC percentages were calculated by considering the nine common terpenes and performed normalization between them totaling $100 \%$.

\section{Results and Discussion}

Eleven samples donated by patients were from plants cultivated in Rio de Janeiro state and one sample was from plant cultivated in São Paulo. The geographical region, growing conditions, names of varieties reported by growers and THC/CBD ratios are showed in Table 1. Only the specimens reported as Harle-Tsu variety met the criteria for classification as hemp

Table 1 - Description of the Cannabis samples.

\begin{tabular}{ccccc}
\hline Variety & Grow condition & City (region) & Sample coding & THC/CBD ratio \\
\hline Amnesia Haze & outdoor & Xerém & SP001 & 74.0 \\
24 K Gold & outdoor & Xerém & SP002 & 22.5 \\
Cannatonic & outdoor & Paraty & SP003 & 9.8 \\
Og Kush & indoor & Rio de Janeiro (North) & SP004 & 33.0 \\
Cinderella & outdoor & Xerém & SP005 & 320.0 \\
Caetano Veloso & indoor & Rio de Janeiro (South) & SP006 & 90.0 \\
Tolomelli & indoor & Rio de Janeiro (North) & SP007 & 12.5 \\
Tolomelli & indoor & Rio de Janeiro (North) & SP008 & 0.8 \\
Harle-Tsu & indoor & Rio de Janeiro (South) & SP009 & 0.1 \\
Harle-Tsu & outdoor & São Paulo (East) & SP010 & 0.1 \\
Harle-Tsu & indoor & Rio de Janeiro (South) & SP011 & 0.1 \\
Harle-Tsu & indoor & Rio de Janeiro (North) & SP012 & 0.1 \\
\hline
\end{tabular}


according UNODC (2009) and American Herbal Pharmacopoeia (2013). The determination of THC/ CBD ratios is necessary because hemp varieties are recommended for the manufacture of seizure control drugs.

The HS-SPME extraction and analytical method provided sufficient sensitivity to identify terpenes with abundance above $1 \times 10^{5}$ TIC. The Figure 1 shows the separation of 30 compounds and the Table 2 shows the identification of terpenes with abundance above $1 \times 10^{5}$ TIC in the chromatogram.

The HS-SPME extraction is a non destructive method and only $100 \mathrm{mg}$ of sample is required for terpenes analysis by GC-MS and the same sample can be used to quantify cannabinoids by HPLC method.

Peak identifications were then assigned using MS spectral matching against reference spectra in the Wiley, NIST libraries and LRI. The identified terpenes were similar to those found previously in the analysis of dried Cannabis (Giese et al. 2015; Mariotti et al. 2016). A review article referred the monoterpenes myrcene, $\alpha$-pinene, limonene and linalool and the sesquiterpenes $\beta$-caryophyllene, $\alpha$-humulene, bisabolol and (E)- $\beta$-farnesene as the most common terpenes present in Cannabis varieties (Booth \& Bohlmann 2019).

Nine terpenes $(\alpha$-pinene, $\beta$-pinene, $\beta$-myrcene, D-limonene, terpinolene, linalool, caryophyllene, $\alpha$-bergamotene and humulene) were present in all samples and could be used as complementary chemical markers in the qualification of the Cannabis genus plants. In order to compare the proportion of each nine terpenes in the samples, the relative levels were defined by the relative percentage TIC for each of nine terpenes in comparison with total percentage TIC (Fig. 2). The PCA analysis showed as main components $\beta$-myrcene, $\alpha$-pinene, caryophyllene and terpinolene (Fig. 3). The Harle-Tsu samples showed two different profiles, two samples showed caryophyllene as main component and the others two presented $\beta$-myrcene as major component.

The varieties identified as Cannatonic, Tolomelli and Caetano Veloso showed more volatile monoterpenes, $\beta$-myrcene and $\beta$-pinene. The variety identified as Cinderella showed the highest level of terpinolene. The later eluting peaks consisted of sesquiterpenes, such as caryophylene, $\alpha$-bergamotene and humulene. The predominance of these compounds could be due to this specific strain of Cannabis, or the nature of the sample tested, which was dried. The level of this compound should increase significantly in relation to other terpenes and terpenoids with drying. Consequently, the levels of the monoterpenes would be expected to be smaller, what was observed to some degree, especially in the hemp varieties (AHP 2013; Giese et al. 2015; Sterneson \& Halpenny 2017). Among the monoterpenes and terpenoids the most abundant were $\alpha$-pinene, $\beta$-pinene, $\beta$ - mircene, D-limonene. The varieties identified as "Og Kush", "Cinderella" e "24K Gold" showed the lowest relative levels of $\alpha$-pinene. Perhaps the relative low levels of monoterpenes in some samples can be attributed to drying conditions or even transport conditions to the laboratory.

The Cannabis samples analyzed in the present study were cultivated in different conditions

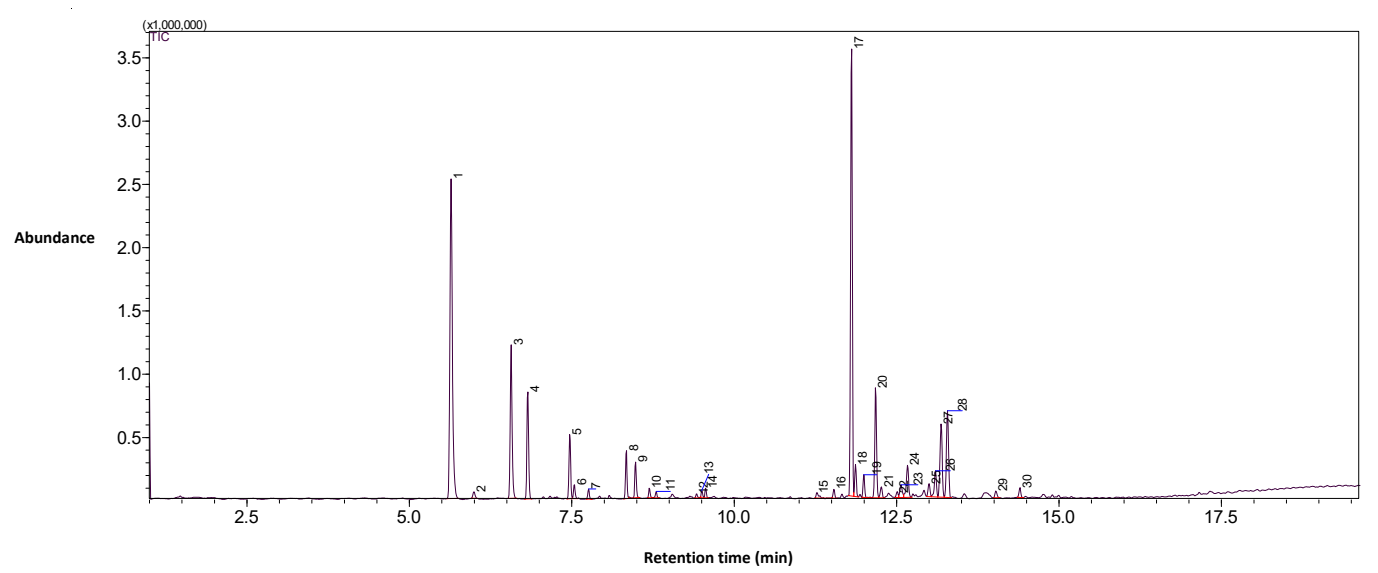

Figure 1 - Chromatographic profile of Cannabis variety Tolomelli, SP008. 
Table 2 - Terpenes identified in Tolomelly variety, SP008.

\begin{tabular}{|c|c|c|c|c|c|c|}
\hline Peak $^{1}$ & Name & Chemical Structure & $\begin{array}{c}\text { Retention } \\
\text { Time }\end{array}$ & Cal RI & Lit RI & $\begin{array}{c}\text { Similarity } \\
\text { Index }\end{array}$ \\
\hline 1 & $\alpha$-Pinene & & 5.642 & 948 & 940 & 97 \\
\hline 2 & Camphene & & 6.008 & 954 & 953 & 97 \\
\hline 3 & $\beta$-Pinene & & 6.567 & 943 & 964 & 97 \\
\hline 4 & $\beta$-Myrcene & & 6.825 & 958 & 955 & 96 \\
\hline 5 & D-Limonene & & 7.467 & 1018 & - & 97 \\
\hline 8 & Terpinolene & & 8.342 & 1052 & 1085 & 96 \\
\hline 9 & Linalool & & 8.483 & 1082 & 1080 & 97 \\
\hline 10 & Fenchol & & 8.683 & 1110 & 1121 & 95 \\
\hline 16 & Santalene & & 11.682 & 1412 & 1420 & 96 \\
\hline 17 & Caryophyllene & & 11.808 & 1494 & 1444 & 95 \\
\hline
\end{tabular}




\begin{tabular}{|c|c|c|c|c|c|c|}
\hline Peak $^{1}$ & Name & Chemical Structure & $\begin{array}{c}\text { Retention } \\
\text { Time }\end{array}$ & Cal RI & Lit RI & $\begin{array}{c}\text { Similarity } \\
\text { Index }\end{array}$ \\
\hline 18 & $\alpha$-Bergamotene & & 11.867 & 1430 & 1433 & 97 \\
\hline 20 & Humulene & & 12.175 & 1579 & 1477 & 96 \\
\hline 23 & $\beta$-Elemene & & 12.567 & 1398 & - & 91 \\
\hline 24 & $\beta$-Bisabolene & & 12.667 & 1500 & 1506 & 92 \\
\hline 25 & $\alpha$-Gurjunene & & 13.000 & 1419 & 1408 & 90 \\
\hline 26 & Valencene & & 13.183 & 1474 & 1491 & 92 \\
\hline 27 & Alloaromadendrene & & 13.283 & 1386 & 1453 & 96 \\
\hline 28 & Selina-3,7(11)-diene & & 13.302 & 1538 & 1542 & 96 \\
\hline 29 & Guaiol & & 14.023 & 1612 & 1605 & 92 \\
\hline 30 & Eudesmol & & 14.400 & 1656 & 1655 & 94 \\
\hline
\end{tabular}

Note: 'peaks identified in SP008, Figure 1; Cal RI: Calculated Retention Index; Lit RI: Literature Retention Index. 


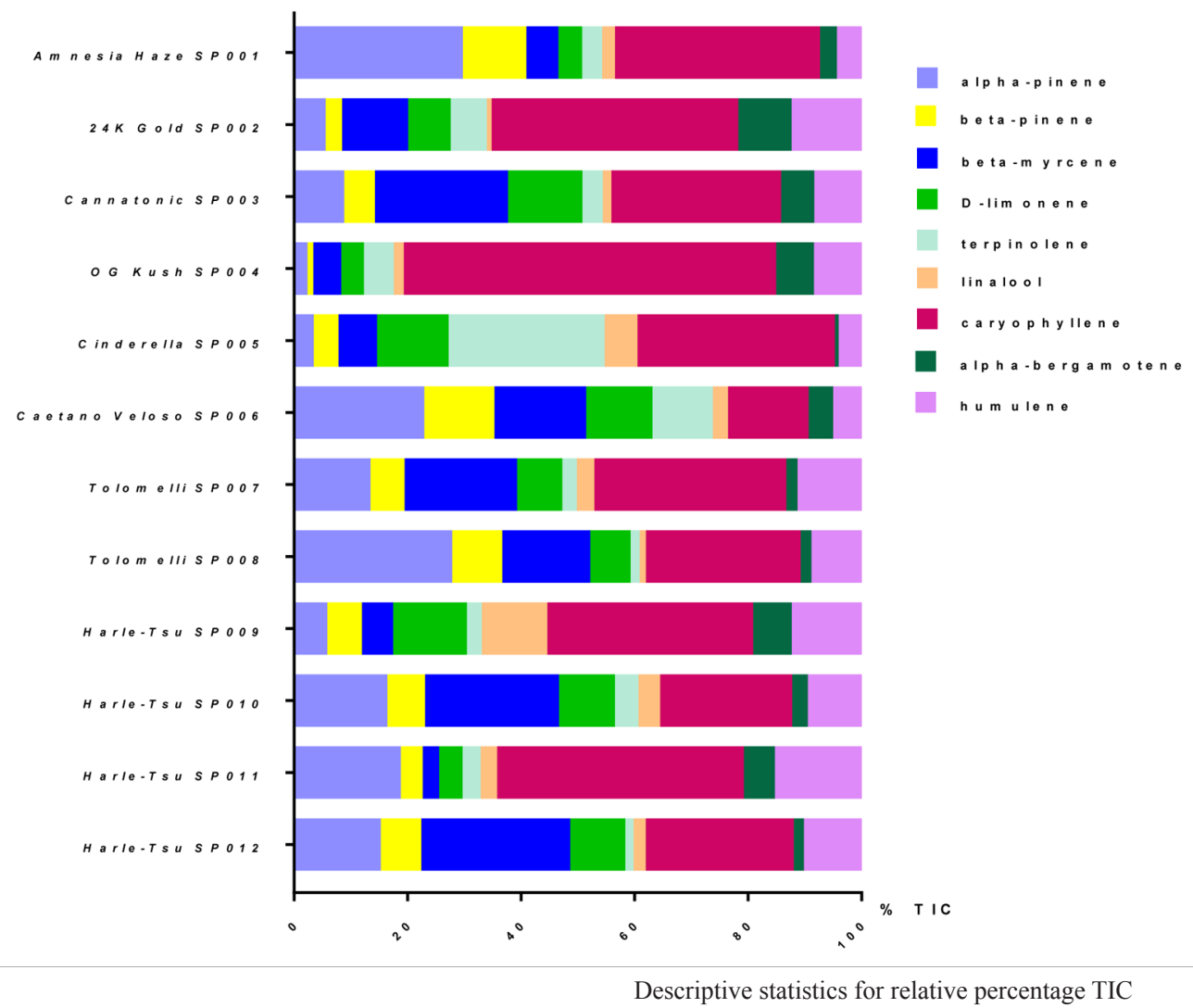

\begin{tabular}{|c|c|c|c|c|c|c|c|c|c|}
\hline & $\alpha$-pinene & $\beta$-pinene & $\beta$-myrcene & D-limonene & terpinolene & linalool & caryophyllene & $\alpha$-bergamotene & humulene \\
\hline Mean & 13.8 & 6.3 & 13.5 & 8.7 & 6.0 & 3.3 & 34.5 & 4.2 & 9.5 \\
\hline Range & $2.0-29.4$ & $1.0-12.4$ & $2.8-26.3$ & $4.0-13.1$ & $1.5-27.5$ & $0.9-11.6$ & $14.2-65.6$ & $0.7-9.4$ & $4.4-15.7$ \\
\hline SD & 9.3 & 3.3 & 8.4 & 3.5 & 7.2 & 2.9 & 12.8 & 2.6 & 3.5 \\
\hline
\end{tabular}

SD: standard deviation; TIC: total ion current.

Figure 2 - Distribution of seven terpenes present in Cannabis samples.

(indoor and outdoor) by different growers and in different geographical regions. The hour of harvest and dry conditions (time between 7 and 15 days) were also variables and even within this variability nine terpenes were in all samples. The results indicate the potential of the group of nine terpenes composed by $\alpha$-pinene, $\beta$-pinene, $\beta$-myrcene, D-limonene, terpinolene, linalool, caryophyllene, $\alpha$-bergamotene and humulene as complementary markers in the identification of Cannabis.

In conclusion, the present study showed the application of a simple and effective method for terpenes analysis in Cannabis specimens that serves as a tool for screening procedure in quality control of the raw material and help the taxonomic discrimination. Additionally, the collected information may contribute to research studies about the alleged entourage effect of the different components in the plants.

\section{Acknowledgements}

The authors gratefully acknowledge finantial support from the Serrapilheira Institute (grant number Serra-1709-18891), the Conselho Nacional de Desenvolvimento Científico e TecnológicoCNPQ, Brasil (Process Number-426406/2018-4) and the Fundação Carlos Chagas Filho de Amparo à Pesquisa do Estado do Rio de Janeiro (Process Number-E26/010.000230/2017 and Process Number-E26/010.101037/2018). 


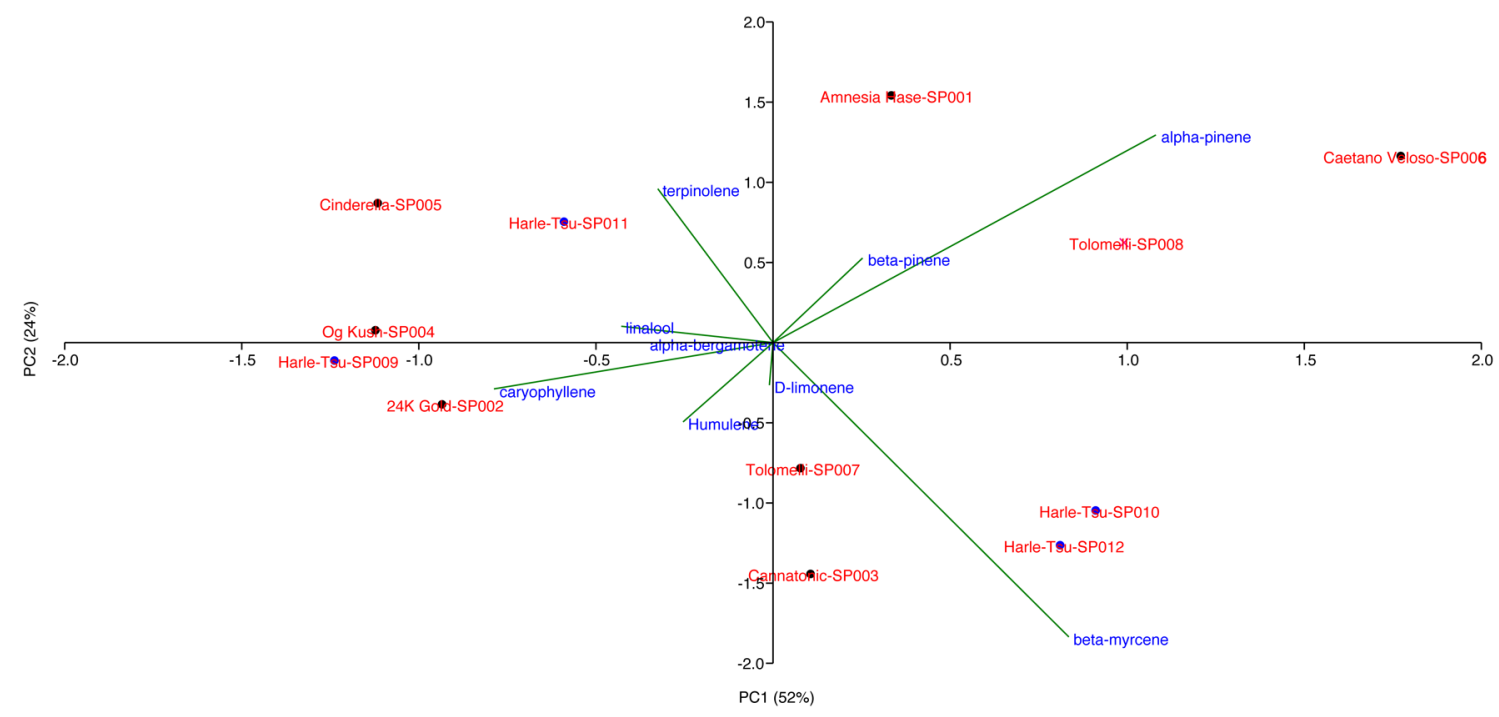

Figure 3 - Principal Component Analysis (PCA) of nine terpenes identified in Cannabis samples cultivated by patients.

\section{References}

AHP - American Herbal Pharmacopoeia (2013) Cannabis inflorescence. Cannabis spp. Standards of identify, analysis, and quality control. 65p. Available at $<$ https:/herbal-ahp.com/collections/frontpage/ products/cannabis-inflorescence-quality-controlmonograph>.

Adams TB \& Taylor SV (2010) Safety evaluation of essential oils: a constituent-based approach. In: Baser KHC \& Buchbauer G (eds) Handbook of essential oils: science, technology, and applications. CRC Press, Boca Raton. Pp. 185-208.

Bassolé IHN, Lamien-Meda A, Bayla B, Tirogo S, Franz C, Novak J, Nebié RC \& Dicko MH (2010) Composition and antimicrobial activities of Lippia multiflora Moldenke, Mentha x piperita L. and Ocimum basilicum $\mathrm{L}$. assential oils and their major monoterpene alcohols alone and in combination. Molecules 15: 7825-7839.

Booth JK \& Bohlmann J (2019) Terpenes in Cannabis sativa - From plant genome to humans. Plant Science 284: 67-72.

Buchbauer G, Jirovetz L, Jager W, Plank C \& Dietrich H (1993) Fragrance compounds and essential oils with sedative effects upon inhalation. Journal of Pharmaceutical Sciences 82: 660-664.

Carvalho VM (2017) Farmacannabis-UFRJ: the first laboratory in Brazil to analyze therapeutic products derived from Cannabis. Brazilian Journal of Analytical Chemistry 4: 44-49.

De Backer B, Debrus B, Lebrun P, Theunis L, Dubois N, Decock L, Verstraete A, Hubert P \& Charlier C (2009) Innovative development and validation of and HPLC/DAD method for the qualitative and quantitative determination of major cannabinoids in Cannabis plant material. Journal of Chromatography B 877: 4115-4124.

Giese MW, Lewis MA, Giese L \& Smith KM (2015) Development and validation of a reliable and robust method for the analysis of cannabinoids and terpenes in Cannabis. Journal of AOAC International 98: 1503-1522.

Hill KP (2015) Medical marijuana for treatment of chronic pain and other medical and psychiatric problems. A clinical review. Journal of American Medical Association 313: 2474 -2483.

Honório KM, Arroio A \& Silva ABF (2006) Aspectos terapêuticos de compostos da planta Cannabis sativa. Química Nova 29: 318-325.

INPI - International Plant Names Index (2020). Available at $<$ https://www.ipni.org/?q=Cannabis $>$. Access on 06 April 2020.

Iseppi R, Brighenti V, Licata M, Lambertini A, Sabia C, Messi P, Pellati F \& Benvenuti S (2019) Chemical characterization and evaluation of the antibacterial activity of essential oils from fibre-type Cannabis sativa L. (Hemp). Molecules 24: 2302.

Langenheim JH (1994) Higher plant terpenoids: a phytocentric overview of their ecological roles. Journal of Chemical Ecology 20: 1223-1279.

Mariotti KC, Marcelo, MCA, Ortiz RS, Borille BT, Reis M, Fett MS, Ferrão MF \& Limberger RP (2016) Seized cannabis seeds cultivated in greenhouse: A chemical study by gas chromatography-mass spectrometry and chemometric analysis. Science and Justice 56: 35-41. 
Pavlovic R, Nenna G, Calvi L, Panseri S, Borgonovo G, Giupponi L, Cannazza G \& Giorgi A (2018) Quality traits of "cannabidiol oils": cannabinoids content, terpene gingerprint and oxidation stability of European commercially available preparations. Molecules 23: 1230.

Potter D (2004) Growth and morphology of medicinal cannabis. In: Guy GW, Whittle BA \& Robson P (eds.) Medicinal uses of Cannabis and cannabinoids. Pharmaceutical Press, London. Pp. 17-54.

Potter DJ (2009) The propagation, characterization and optmisation of Cannabis sativa $\mathrm{L}$. as a phytopharmaceutical. Doctor of Philosophy thesis. King's College, London. 224p.

Ross SA \& ElSohly MA (1996) The volatile oil composition of fresh and air-dried buds of Cannabis sativa. Journal of Natural Products 59: 49-51.
Russo EB (2011) Taming THC: potential cannabis synergy and phytocannabinoid-terpenoid entourage effects. British Journal of Pharmacology 163 : 1344-1364.

Silva RAD (1929) Pharmacopeia dos Estados Unidos do Brasil. Cia. Editora Nacional, Rio de Janeiro. Pp. 160-161.

Sterneson KK \& Halpenny MR (2017) Analysis of terpenes in cannabis using headspace solid-phase microextraction and GC-MS. LC-GC North America 35: 28-39.

UNODC - United Nations Office on Drugs and Crimes (2009) Recommended methods for the identification and analysis of cannabis and cannabis products. Manual for use by national drug analysis laboratories. United Nations, New York. 60p. 